\title{
BEITRAGE ZUR PRAEPOSITIONSLEHRE IM NEUENGLISCHEN.
}

In dem vorwort zu meinen 'adverbialen zeitverhältnissen' (Halle. Gesenius. 1876) hatte ich geglaubt, eine baldige fortsetzung der tibrigen adverbialen verhältnisse in aussicht stellen zu können. Indessen verzögert sich die sache doch länger, als ich erwartet, da manche schwierigere punkte mich in eine ganze reihe von einzeluntersuchungen verwickeln. Wie nun dort nur die resultate eine stelle gefunden, z. b. tuber den gebrauch von in the reign $=$ wnter der regierung, ausfuhrlicher dagegen in Herrigs archiv 55, 2 daruber berichtet ist, so durften ähnliche mitteilungen auch uber andere präpositionen ein allgemeines interesse haben. Jedenfalls werden die zahlreichen beispiele, welche auf treu und glauben angenommen werden können, wenn ich auch untierlassen habe, wegen der verschiedenheit der ausgaben nach seite und zeile zu citiren, bei der grossen dtirftigkeit und unzuverlässigkeit selbst der besten wörterbticher vielen willkommen sein.

\section{I. to expect from. \\ to expect of.}

Mätzner, englische grammatik II. 1, 233, sagt: 'die tätigkeitsbegriffe: verlangen, begehren, erwarten, erfragen und ähnliche, wie beg, want, crave, desire, entreat, require, request, expect, ask, demand, enquire etc. lassen of beim personalobjekte zu.'

Als einziges beispiel findet sich fur expect angegeben:

That is more than I expected of you. Scott. Bride 7. Weiter heisst es dann: 'nebem of steht from', doch ohne bejegstellen fur expect.

Näheren aufşchluss tuber etwaige verschiedenheiten in dem gebrauche von from und off geben weder Johnson noch ein anderes wörterbuch, in denen man selbst nach einem beispiele vergebens sucht.

Gleichwol besteht ein unterschied in dem sprachgebrauche, wie sich aus den nachsteheniden beispielen ergibt, wenn auch die grenze - wie dies bei from und of therhaupt der fall ist - nicht immer ganz scharf zu ziehen ist. 
Einen weiteren anhaltspunkt bietet

to hear from a person by receiving a message,

a letter from him.

to hear of a person $=$ about.

to come from, kommen von (örtlich, causal).

to come of, in weiterer bedeutung $=$ to

be descended from.

From findet sich

1. in allen fällen, wo expect (erwarten) ein sächliches objekt bei sich hat und den nebenbegriff des erhaltens, bek ommens (get, receive) in sich schliesst.

Incite them to quick motion; for I must

Bestow upon the eyes of this young couple

Some vanity of my art; it is my promise

And they expect it from me.

Shak. Tp. 4, 1, 42.

I expect from you that you should love me.

Lady Montague. Lett.

My daughter-in-law, from whom I expected most, has lost the beauty and gaiety of youth.

Johnson. Lett.

Nor can we expect from your lordships, in this court, but the sentence which the lan requires.

Id. Savage.

Therefore he no longer expected any assistance from them.

Id.

From whom he expected an associate in his studies.

Id. Rambl. 17.

She will expect more att ention from you, as my friend. H. Walpole. Lett.

I see that it is vain to expect happiness from him who has been so bad an economist of his own.

Goldsm. G. M. 4.

It would be madness to expect happiness from one who has been so bad an economist of his own.

$$
\text { Id. } V \text {. of } W \text {. }
$$

And so you would expect a reward from me. Id.

We expect a visit from him shortly.

Id.

The less kind $I$ found fortune at one time, the more I expected from her another.

Id.

Never more, therefore, expect friendship from me. Id. 
I expect a message from Mrs. Malaprop.

Sherid. Riv. 2, 1.

From the Silesians the utmost that he could expect was apathy.

Macaul. Fred.

From the Silesian catholics he could hardly expect anything but resistance.

Id.

$I$ must confess myself surprised by your application; I did not expect it from you.

Austen. Pride Pr.

It was intolerable to her that Klessmer should imagine her to have expected other help from him than advice.

Eliot. D. Deronda.

She must expect no further assistance from me. Id.

Ebenso auch expectation, wobei das săchliche object naturlich im genitiv steht.

The author, in expeclation of an Epilogue from a friend at Oxford, deferred writing one himself.

Goldsm. G. M. Epil.

All expectation from the brother was now absolutely over. Austen. Pride Pr.

Anm. Mehr oder weniger hängt in allen diesen fällen das from schon von dem sachobjekte ab, und es heisst ebenso z. b. a message from Mrs. Malaprop, wie I expect a message from Mrs. Malaprop.

2. in allen fällen wo expect im passiv steht und der nebenbegriff des transitiven bekommens in den des intransitiven kommens abergeht.

Even the greatest actions of a celebrated person are no more than what are expected from him.

Spect.

You have children from whom much pleasure may be expected.

Johns. Lett.

I feel the want of that tender care of me which might be expected from a daughter.

Frankl. Lett.

His own exertions were such as were hardly to be expected from a human body or a human mind. Mac. Fred.

What sort of issue might be fairly expected from all this self-denial?

Eliot D. Deronda.

3. in allen fallen, wo won nicht mit einer person, sondern mit einem sächlichen begriffe, auch mit folgendem verkturten satze (davon dass) verbunden ist.

He expected nothing but downright raillery from that side.

Spectator. 
My brother hears this with more courage than I could have expected from his warm passions.

H. Walpole, Lett.

Imagine what pleasure we expected from the sight of a fer gumtrees.

Johns. Rambl. 34.

He felt that loss more than was to be expected from the hardness and severity of his character.

Mac. Fred.

She never expected honesty but from a strong chest.

Johns. Rambl. 34.

She expected no happiness nor advantage but from beauty.

Id. 130.

It is dangerous to omit the cares of husbandry and expect from this ground the blossoms of Arabia. Id. 169.

$I$ tried to determine from which of these tickets I might reasonably expect riches.

Id. 181.

They expect a prize from the next adventure.

Id. 182.

I expect more pleasure from the Cathedrals of Cologne and Strassburg. Mac. Lett.

If a man falls short of what is expected from his former genius in writing.

Richards. Lett.

He explained the ill consequences which might be expected from such a letter.

$I d$.

What better could be expected from being connected with such a stupid fool.

Sher. Riv. 4, 1.

She made a variety of remarks on the happiness that might be expected from the match. Austern. Pride Pr.

Mr. G. did not expect any success from this measure.

Id.

Expecting the regeneration of mankind from the effect of educated intellect enlightening the selfish feelings.

Mac.

Shining forth as might be expected from the planets of genius and fortune in conjunction.

Eliot. D. Deronda.

You had equal expectations from your last schemewith Miss Richard.

Goldsm. G. M. 2.

4. in den meisten fällen, wo sich neben der person noch ein sächliches object findet. Auch dies gilt gleicherweise für das passiv.

The Epistle has less wit by far than I expected from him.

H. Walpole, Lett. 
From you I expect the result of Mr. G's. studies and discoveries on the subject.

Richards. Lett.

He was forced to own the folly of expecting punctuality from the poor.

Johns. Swift.

I have long expected somiething remarkable from you.

Eliot. D. Deronda.

He wrote a poem on her dieparture, only, as he declared, because it was expected from: him.

Johns. Savage.

There was a certain naturaal grace and decorum hardly to be expected from a man...

Mac. Goldsm.

I exhibit as much family affection and humane interest as could be expected from mee.

Bulw. Ken. Chill.

of dagegen steht,

wenn expect, erwarten in den begriff des denkens, meinens ubergeht. Damit kann dann nicht ein sächliches objekt verbunden werden, sondern nur ein allgemeiner ausdruck, wie it (auf einen vorhergehendlen satz bezogen), what, nothing, as much as, as, than u. ähnl.

1 expect much from him, ich erwarte viel von ihm, d. h. $\mathrm{zu}$ erhalten.

I expect much of him, ich erwarte viel von ihm, d. h. ich habe eine grosse meinung von ihm.

Ebenso What do you expect from him? und

What do you expect of him?

Eine vergleichung der untcer 4. angefuhrten beispiele wird dies im einzelnen bestätigen. Sio bezieht sich in it was expected from "it" auf das vorhergehemde poem, während es auch of heissen könnte, wenn it sich æuf das prädikat bezöge und zu ergänzen wäre that he should morite.

The epistle has less wit by far than 1 expected from him, (Walp. Lett.) weil $=I$ expectted more wit from him; aber In the epistle he shows less wit byy far than $I$ expected of him $=$ 1 expected that he would show more wit. 1 exhibit as much family affection as could be expeeeted from me $=$ as much family affection could be expected froom me; dagegen as much family affection was exhibited as couldl be expected of me $=$ as could be expected that I should exhibbit, oder as I could be expected to show.

He hath, indeed, better bettered expectation, than you must expect of me to tell you how.

Shak. Ado. 1, 1, 17. 
Margaret, perhaps, expected it of me, for she looked hard in his face.

Bulw. Mltr.

What other people might have expected of him.

Eliot. D. Deronda.

Not knowing what might be expected of the ancient hero.

Id.

She devised little schemes for learning what was expected of men in general.

Eliot. D. Deronda.

$I$ did not want to be an artist; but this was what my father expected of me.

Id.

What better could be expected of a pock-pudding English folk?

What do I expect of Dublin?

Scott. R. R.

of Doctor P. nothing better was to be expected.

Poe. Tales.

$S$. hat done as much as could be expected of her.

Eliot. D. Deronda.

He returned Anna's affection as fully as could be expected of a brother.

Id.

It was a less judicious action than I should have expected of the Duchess.

Id.

Why is it to be expected of an heiress that she should marry?

Id.

Anm. 1. Einen zuverlässigen anhalt für den gebrauch des from oder of bietet die passive construction, welche zugleich die stelle des deutschen man vertritt.

Bei $t o$ be expected from findet sich wie im Deutschen nur die sache als subjekt.

Ein geschenk wird $\nabla$ on mir erwartet, oder $m a n$ erwartet ein geschenk von mir, heisst nur $A$ present is expected from me, nicht aber I am expected a present.

(Vergl. die beispiele unter 2.)

Of course a small donation is expected from the inmates of each house visited.

Chamb. J.

Bei to be expected of ist dagegen das subject stets ein allgemeiner begriff, d. h. ein pronomen oder ein satz.

The addition of his income was not proportionate to the duties expected of him (Graphic) ist nicht als mustergultig zu betrachten, da es nur dem Policereport entlehnt ist. Und keine regel ohne ausnahme.

Und wie bei 'man sagt von mir', neben it is said of me, it is said that $I$ gewöhnlich die pers 8 nliche construktion $I$ am said to eintritt, so auch bei 'man erwartet von mir, dass ... I I am expected to. 
Daneben findet sich anch hier die unpersonliche construktion: it is expected that $I$. . .

It was put to you, and it is expected that you should answer it.

Bunyan. P.P.

- It could not be expected that 1 should now cast in my lot with thieves.

Id.

By whom it was expected that he would have been in a very short time enlarged.

Johns. Sav.

1 cannot be expected to say much of a life. Johns. Swift.

$H e$ was exp ected to do everyman's business.

Id.

So würden die obigen beispiele auch heissen können:

She had done as much as she could be expected to do (as much as hängt also von to do, nicht von expect ab).

He returned Anna's affection as fully as a brother could be expected to do.

It was a less judicious action than the duchess could be exp ected to have done.

In diesen fällen ist die andere ausdrucksweise vorgezogen, weil sie kürzer ist und die wiederholung des to do, to have done dadurch vermieden wird. Ebenso erhält das: Why is it to be expected of an heiress that she should marry? eine färbung, welche der an sich gleich guten redeweise: Why is an heiress to be expected to marry abgeht, abgesehen von dem harten klange des to be expected to marry, der sich freilich hätte vermeiden lassen in Why should an heiress be expected to marry?

Anm. 2. Der vollständigkeit wegen mag noch to expect mit folgendem acc. und inf. oder einem objectsatze mit that angefihrt werden.

Mine host expected his commercial guest to drink wine at dinner. Chamb. 1 .

The master expecteth, that thou shouldst stand in his presence. Bunyan. P. P.

Nur scheinbar ist die a $\mathrm{s} \mathrm{nahme}$ in: Looking meeker than $\mathrm{Mr}$. Winkle had expected from a gentleman of his ferocity $=$ als or es sich versehen hatte von seiten eines herrn. Dick. Pick. Dafur konnte es auch heissen: than $M r$. W. had expected of a gentleman of his ferocity, oder passivisch: a gentleman of his ferocity was expected to look meeker. Möglich immerhin, dass from gewählt, einesteils um die wiederholung des of a gentleman of his ferocity zu vermeiden, andernteils weil looking meeker weniger allgemeiner begriff ist.

Das gilt ebenso unter umständen von what. In dem obigen beispiele: what do you expect of Dublin? ist what allgemein, nach ana-. logie von 'was denken Sie oder wie denken Sie von? What do you' expect from Dublin? heisst dagegen nur was, welchen gegen- stand erwarten Sie von d. h. aus Dublin? Aehnlich what from: thy thankless arms can we expect. Pope. II. 17, 165. 
In dieser mehr substantivischen bedeutung steht dasselbe noch: My studies had taught me what to expect from the orthodox Jew. Eliot. D. Deronda; = das mass dessen, was ich zu erwarten hatte. Denn passivisch kann es nicht lauten: the orthodox Jen-what? oder something, sondern so much was expected from the Jew.

$\mathrm{Zum}$ schlusse noch einen weiteren beleg. Lucas führt in seinem wörterbuche an: 'das hätte ich mir von ihm nicht vorausgesehen, I should not have expected that from (of) him.'

I should not have expected that from him: ich würde das, nämlich eine bestimmte tatsache, eine solche behandlung nicht von ihm erwartet haben.

1 should not have expected that of him $=I$ should not have tho ught that of him; I should not have expected him to do so.

Ferner: 'ich versehe mich eines besseren zu euch: I expect better things of you' - nun ja, besseres ist hier abstrakt. I expect better things from you hiesse: ich erwarte bessere sachen von euch.

Anm. 3. I a m, quoth he, expected of my friends. Shak, Ven. 718.

Moreover, it is expected of some, that this Prince will shortly come into these parts.

Bunyan. P. P.

In der älteren sprache findet sich bei to be expected einzeln of statt des sonst beim passiv üblichen by.

Bremen.

W. SATTLER.

\section{DER DICHTER HUCHOWN UND SEINE WERKE.}

I.

\section{DIE HUCHOWN-FRAGE.}

Wyntown spricht im zwölften kapitel des fünften buches seiner schottischen chronik von einem dichter namens Huchown of the Awle Ryale. Er entschuldigt Huchown, dass er den Lucius Iberius, der doch eigentlich procurature gewesen sei, emperoure nenne, rthmt seine dichterische begabung, führt die von ihm geschriebenen werke an und gibi von einem derselben den inhalt. Die chronik Wyntown's ist leider bis jetzt ein ausserst seltenes buch in Deutschland; ich bringe deshalb die 